\title{
PELAKSANAAN WEBINAR MENTAL HEALTH PADA MAHASISWA JURUSAN KEBIDANAN
}

\author{
Ni Wayan Sukma Adnyani' ${ }^{1}$ Anggreny Gita Loka ${ }^{2}$ \\ 1,2 Politeknik Kesehatan Kartini Bali
}

E-mail korespondensi: sukmaadnyani@gmail.com

\begin{tabular}{ll}
\hline Article History: & Abstrak: \\
\hline Received: 28-12-2021 & Latar Belakang: Pandemi COVID-19 saat ini sedang banyak \\
Revised: 29-12-2021 & dibicarakan dan menimbulkan berbagai macam dampak \\
Accepted: $29-1$ & termasuk dalam pembelajaran daring. Kesenangan \\
& pembelajaran daring hanya dirasakan diawal saja, selebihnya \\
& rasa bosan, malas sebagapi pemicu stres muncul sampai \\
& akhirnya muncul masalah lainnya yang dapat berdampak \\
& pada kesehatan mental. Kuesioner awal yang diberikan pada \\
& 26 siswa kebidanan terdapat 2 orang (7,7\%) dengan katagori \\
& stres berat sehingga hal ini perlu mendapatatkan perhatian \\
& khusus dari Institusi terkait pengelolaan kesehatan kepada \\
& siswa kedepannya.
\end{tabular}

Kata Kunci:

Pembelajaran daring, webinar mental health, pandemi Covid-19

Keywords:

Online learning, mental health webinars, pandemic Covid-19
Metode: Sasaran pengabidan ini adalah mahasiswa DIII kebidanan sejumlah 26 orang. Metode yang digunakan dalam pelaksanaan Pengabdian ini dengan mengadakan webinar terkait Mental health pada mahasiswa dan pemberian kuesioner post test dengan menilai aspek pengetahuan dan tingkat stress yang dirasakan mahasiswa selama menjalani pembelajaran daring pada masa pandemi COVID-19.

Hasil: Selain melihat dari sisi akademik siswa adanya pelaksanaan kegiatan pengabdian kepada masyarakat dalam bentuk webinar mental health ini diharapkan adanya perhatian khusus terhadap mahasiswa khususnya terkait kesehatan mental saat pembelajaran daring pada saat pandemi serta untuk kegiatan selanjutnya adanya pembinaan tutor teman sebaya guna memfasilitasi mahasiswa yang memiliki kendala selama pembelajaran daring.

\section{Abstract:}

Background: The COVID-19 pandemic is currently being discussed a lot and has various impacts, including online learning. The fun of online learning is only felt at the beginning, the rest is boredom, laziness as a stress trigger until finally other problems arise that can have an impact on mental health. The initial questionnaire given to 26 midwifery students was 2 people $(7.7 \%)$ in the category of severe stress so this needs special attention from the institution regarding health management for students in the future.

Methods: The target of this activity was 26 students of the midwifery DIII program who attended the webinar. The method used is by administering a post-test questionnaire by assessing aspects of knowledge and the level of stress felt by students during online learning during the COVID-19 pandemic. 
Results: In addition to seeing from the academic side of students, the implementation of community service activities in the form of a mental health webinar is expected to pay special attention to students, especially regarding mental health during online learning during a pandemic and for further activities, peer tutoring is expected to facilitate students who have problems during the pandemic. online learning.

\section{Pendahuluan}

Analisis Situasi

Pandemi COVID-19 saat ini sedang banyak dibicarakan dan menimbulkan berbagai macam persepsi, kehawatiran dan berbagai upaya dalam pencegahan wabah penyakit tersebut. Kita ketahui bahwa kesehatan merupakan hal yang utama dan berharga bagi setiap individu. Dengan tubuh yang sehat setiap individu dapat melakukan aktifitas sehari-hari secara produktif, baik secara sosial maupun ekonomis. Pendidikan merupakan salah satu aspek penting yang terkena dampak pandemi ini. Seluruh kegiatan pembelajaran tatap muka dialihkan menjadi pembelajaran daring (Surat Edaran Kemendikbud Dikti No.1 Tahun 2020).

Politekik kesehatan Kartini Bali merupakan Perguruan Tinggi vokasi di bidang kesehatan dimana mahasiswa tentunya akan sering bersentuhan atau berhadapan dengan pasien dalam praktiknya. Direktur Politeknik Kesehatan Kartini Bali dengan mengikuti himbauan dari Pemerintah Pusat telah mengadakan pembelajaran jarak jauh (daring) sejak 16 Maret 2020. Bagi mahasiwa diberlakukannya sistem pembelajaran daring diawal tentunya membawa kabar bahagia, karena mahasiswa tidak perlu tiap pagi untuk berangkat ke kampus, dimana pembelajaran bisa dilakukan dengan waktu yang fleksibel dimana saja. Namun seiring berjalannya waktu pembelajaran daring memiliki beberapa kendala bagi mahasiwa diantaranya permasalahan ketidakstabilan koneksi jaringan internet, adaptasi dengan sistem pembelajaran daring yang baru seperti peggunaan aplikasi virtual meeting, elearning dan aplikasi lainnya, kendala teknis saat dosen memberikan perkuliahan, penugasan yang banyak sampai pada rasa jenuh pada mahasiwa karena kurangnya interaksi yang bisa berdampak pada kesehatan mentalnya.

Studi pendahuluan yang lakukan kepada mahasiswa kebidanan dengan pemberian kuesioner DASS 21 untuk menilai tingkat stress mahasiswa selama pembelajaran daring diperoleh hasil kategori normal berjumlah 12 mahasiswa $(46,2 \%)$, kategori ringan 5 (19,2\%), kategori sedang 7 (26,9\%), dan yang kategori berat $2(7,7 \%)$ mahasiswa dan tidak ada dengan kategori sangat berat.

Pembelajaran daring yang hampir setahun lebih dijalani mahasiswa tentunya memiliki banyak dampak. Kesenangan pembelajaran daring hanya dirasakan diawal saja, selebihnya rasa bosan, malas sebagapi pemicu stres muncul sampai akhirnya muncul masalah lainnya yang dapat berdampak pada kesehatan mental baik disadari maupun tidak disadari. Hal ini dapat berujung pada prestasi akademik yang mulai menurun dan kesulitan dalam beradaptasi. 
Penelitian yang dilakukan Putri et al (2020) diketahui bahwa sebagian besar mahasiswa cenderung mengalami stres tingkat sedang (71\%). Dari hasil penelitian tersebut menyatakan bahwa stresor yang paling menjadi pemicu terjadinya stres pada mahasiswa yaitu fasilitas pembelajaran yang kurang memadai $(40,7 \%)$, kesulitan belajar dalam jangka waktu yag lama $(32,5 \%)$, tugas yang slalu banyak dan beban akademik (23,5\%). Sejalan dengan penelitian diatas Hassanah, dkk (2016) dalam penelitiannya menunjukan hasil tingkat kecemasan mahasiswa sebanyak 79 mahasiswa (41,58\%) dengan tingkat kecemasan ringan, sebanyak 32 ( $16,84 \%)$ dengan kecemasan sedang dengan adanya pembelajaran daring (Nurhasanah, S., \& Sobandi, 2016).

Hasil penelitian yang dilakukan peneliti sebelumnya tentang pembelajaran daring pada mahasiswa Jurusan kebidanan dengan Analisa SWOT dilihat dari faktor internal aspek kelemahan (weeknesses) diperoleh hasil persiapan kuliah daring mulai dari menurunnya motivasi belajar saat pembelajaran daring karena terbatasnya interaksi dan sosialiasai, rasa malas, jenuh dan rasa bosan merupakan penghambat dalam pembelajaran daring. Dilihat dari faktor eksternal berdasarkan aspek ancaman (treat) juga diperoleh hasil mahasiswa sulit berkonsentrasi karena kondisi rumah yang kurang kondusif, kondisi ekonomi keluarga yang tidak stabil selama pandemi, jaringan internet yang kurang stabil menjadi salah satu penghambat sampai penugasan yang cukup banyak (Sukma Adnyani, N., \& Krisda Elvina, 2021).

Apabila dampak negatif ini tidak diberikan perhatian lanjut, maka dapat berpengaruh terhadap kesehat mental mahasiswa. Sehingga dengan adanya kegaiatan Pengabdian kepada masyarakat melalui Webinar tentang Pentingnya menjaga kesehatan mental slama pembelajaran daring penting diberikan kepada mahasiswa untuk meningkatkan pemahaman mahasiswa tentang pentingnya menjaga kesehatan mental dalam kondisi saat ini dan mahasiswa dapat mencegah serta mengatasi apabila terdapat tanda-tanda yang menagarah pada gangguan kesehatan mental.

\section{Metode Pelaksanaan}

Pelaksanaan webinar Mental Health sebagai bagian dari kegiatan pengabdian kepada masayarakat telah dilaksanakan pada tanggal 10 Agustus 2021 secara daring pada mahasiswa Prodi DIII Kebidanan dengan jumlah mahasiswa 26 orang. Kegiatan webinar diawali dengan pemberian materi dan diakhiri dengan pemberian kuesioner terkait pengetahuan dan tingkat stress yang dirasakan mahasiswa selama menjalani pembelajaran daring pada masa pandemi Covid-19. Berikut adalah metode pelaksanaan kegiatan: 


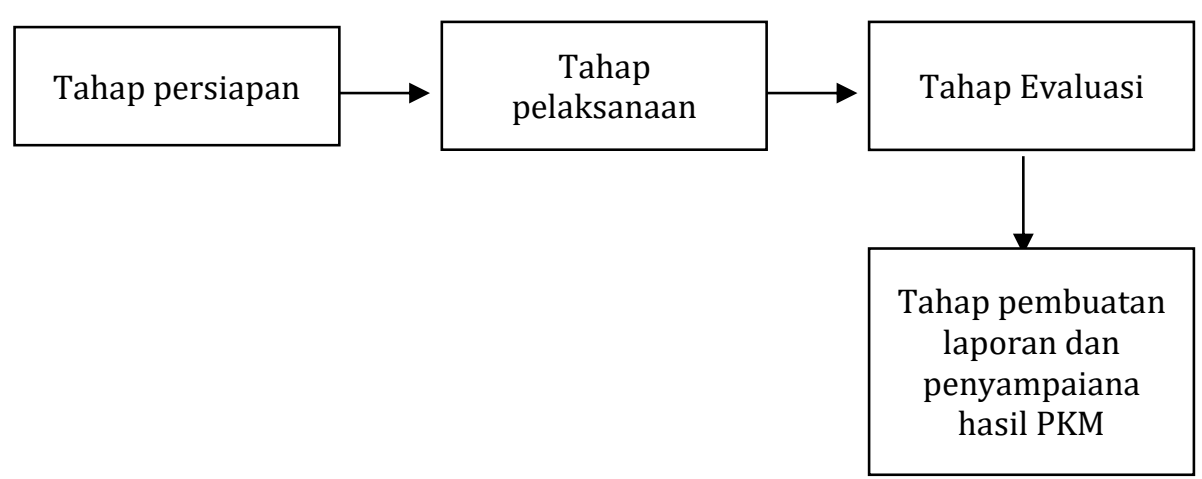

Gambar 1. Metode Pelaksanaan Kegiatan PKM

Gambar diatas dapat dijelaskan sebagai berikut :

a. Tahap persiapan

- Penyusunan proposal usulan kegiatan PKM

- Persiapan kuesioner kegiatan

- Diskusi terkait teknis webinar dan materi

- Penyebaran informasi kepada mahasiswa melalui WA grup

b. Tahap pelaksanaan

- Registrasi peserta webinar

- Pembukaan oleh Mc

- Penyajian materi edukasi oleh narasumber

- Penutupan

c. Tahap evaluasi

- Dskusi/ tanya jawab

- Pemberian kuesioner Post test kegiatan

d. Tahap pelaporan

- Penyusunan laporan kegiatan

- Informasi kepada Mitra terkait hasil kegiatan

\section{Hasil}

Tahap persiapan dalam kegaiatan Pengabdian kepada masayrakat diawal dengan perizinan kepada Insitusi untuk pelaksanaan PKM dengan kegiatan webinar kepada mahasiswa prodi DIII Kebidanan. Pelaksanaan Webinar dilakukan secara daring melalui zoom meeting sesuai dengan jadwal yang diumumkan. Pelaksanaan webinar berlagsung selama 1.30 jam yang diawali dengan pembukaan, penyampaian materi, pemberian kuesioner dan penutup. Kuesioner diberikan untuk menilai tingkat pengetahuan mahasiswa selama pandemi COVID-19. 


\section{Jurnal ABDI MERCUSUAR}

Vol. 01, No. 02, Bulan, 2021, pp. 084 - 090

Hasil kuesioner yang diberikan adalah sebagai berikut:

Tabel 1. Interpretasi Pengetahuan responden tentang kesehatan Mental selama

Pandemi COVID -19

\begin{tabular}{ccc}
\hline Pengetahuan & Jumlah & (\%) \\
\hline Baik & 5 & $19,2 \%$ \\
Cukup & 21 & $80,7 \%$ \\
Kurang & 0 & $0 \%$ \\
\hline
\end{tabular}

Dari tabel 1 diperoleh hasil dari 26 responden (100\%) berdasarkan tingkat pengetahuan diperoleh hasil hampir seluruhnya yaitu 21 responden (80,7\%) dengan pengetahuan cukup dan hampir setengahnya yaitu 5 responden $(19,2 \%)$ dengan pengetahuan baik dan tidak ada dengan pengetahuan kurang terkait menjaga kesehatan mental selama pandemi COVID-19 dan adaptasi kebiasaa baru.

Berikut untuk hasil dokumentasi kegiatan webinar dengan Topik Menajaga Kesehatan Mentak selama Pandemi COVID-19:

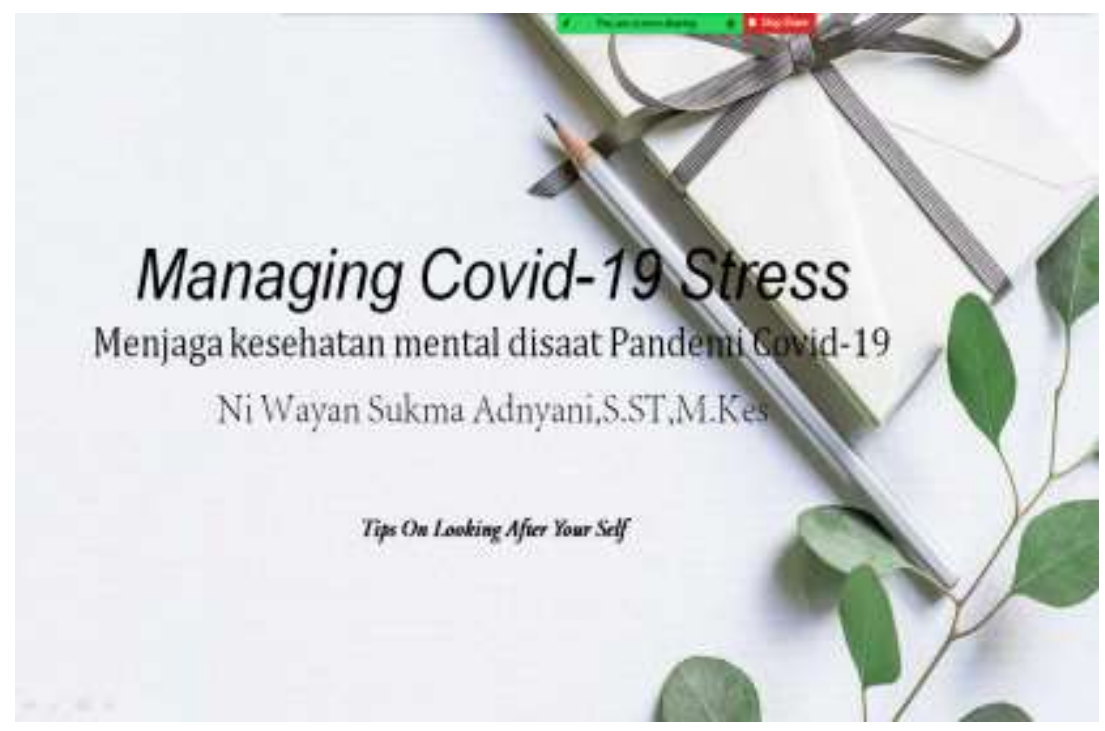

Gambar 2. Materi webinar

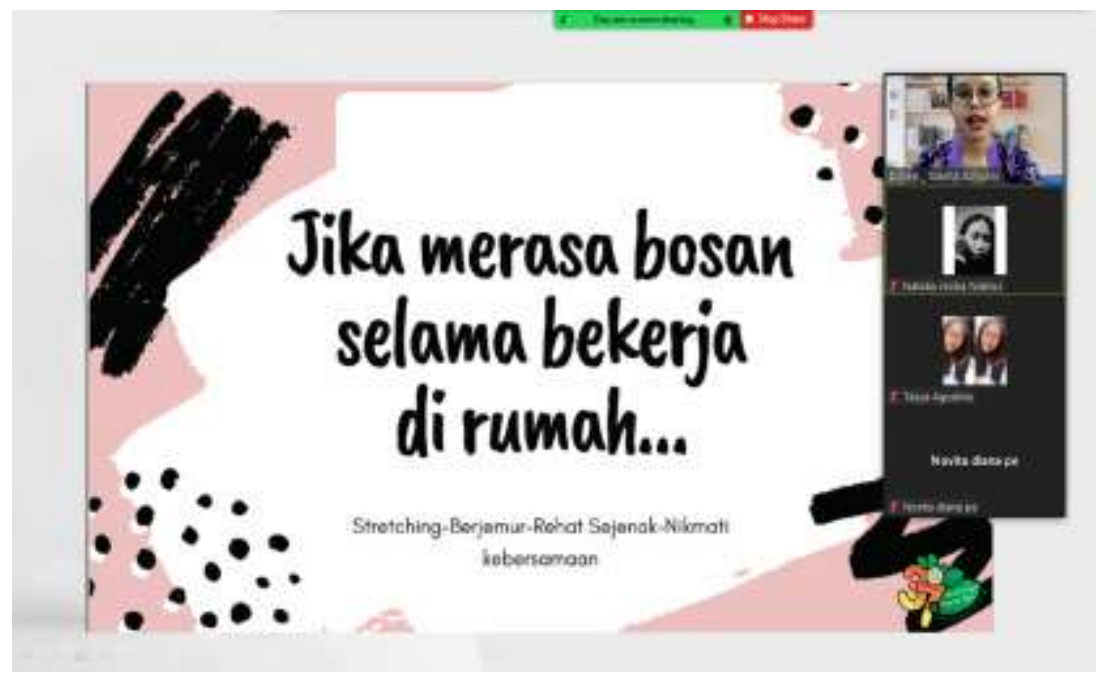


Gambar 3. Pelaksanaan kegiatan webinar

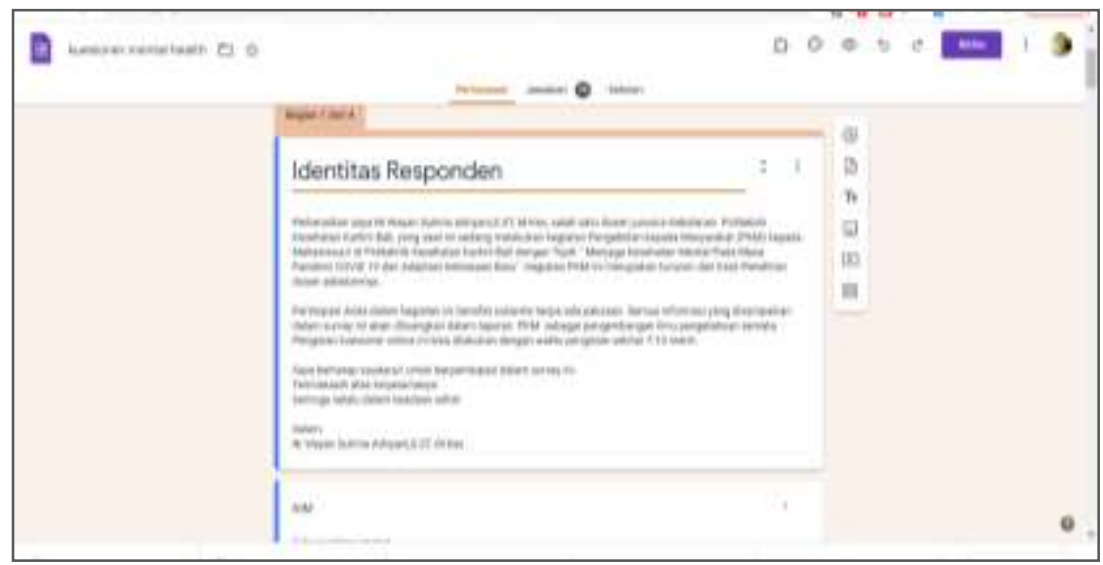

Gambar 4. Kuesioner webinar

\section{Diskusi}

Dari hasil kegiatan yang telah dilakukan berdasarkan tingkat kecemasan yang dirasakan oleh responden selama Pandemi COVID-19 diperoleh hasil bahwa $26,7 \%$ dengan stres sedang dan $7,7 \%$ dengan stress berat. pengetahuan terkait menjaga kesehatan diperoleh hasil $80,7 \%$ dengan pengetahuan cukup dan 19,2 dengan pengetahuan baik. Bagi mahasiwa diberlakukannya sistem pembelajaran daring diawal tentunya membawa kabar bahagia. Namun seiring berjalannya waktu pembelajaran daring memiliki beberapa kendala bagi mahasiwa diantaranya permasalahan ketidakstabilan koneksi jaringan internet, adaptasi dengan sistem pembelajaran daring yang baru seperti peggunaan aplikasi virtual meeting, elearning dan aplikasi lainnya, kendala teknis saat dosen memberikan perkuliahan, penugasan yang banyak sampai pada rasa jenuh pada mahasiwa karena kurangnya interaksi yang bisa berdampak pada kesehatan mentalnya. Kesenangan pembelajaran daring hanya dirasakan diawal saja, selebihnya rasa bosan, malas sebagapi pemicu stres muncul sampai akhirnya muncul masalah lainnya yang dapat berdampak pada prestasi belajar.

Penelitian yang dilakukan Putri et al (2020) diketahui bahwa sebagian besar mahasiswa cenderung mengalami stres tingkat sedang (71\%).Hasil penelitian yang dilakukan peneliti sebelumnya tentang pembelajaran daring pada mahasiswa Jurusan kebidanan dengan Analisa SWOT dilihat dari faktor internal aspek kelemahan (weeknesses) diperoleh hasil persiapan kuliah daring mulai dari menurunnya motivasi belajar saat pembelajaran daring karena terbatasnya interaksi dan sosialiasai, rasa malas, jenuh dan rasa bosan merupakan penghambat dalam pembelajaran daring(Sukma Adnyani, N., \& Krisda Elvina, 2021). 


\section{Kesimpulan dan Saran}

Dampak stress dan rasa malas yang bisa timbul dari pembelajaran daring selama Pandemi COVID-19 sebaiknya diberikan perhatian lebih lanjut.. Adanya kegaiatan Pengabdian kepada masyarakat melalui Webinar ini selain mengukur tingkat pengetahuan dan tingkat stress mahasiswa, kegiatan ini bemanfaat untuk meningkatkan pemahaman mahasiswa tentang pentingnya menjaga kesehatan mental dan mencegah serta mengatasi apabila terdapat tanda-tanda yang berpengaruh terhadap penurunan prestasi belajar. Untuk selanjutnya hasil kegiatan akan diifokan kepada dosen Pembimbing Akademik (PA)untuk terlibat dalam melakukan pendekatan dan memfasilitasi permasalahan mahasiswa selama pembelajaran daring.

\section{Ucapan Terimakasih}

Tim pegabdi mengucapkan terimkasih kepada Yayasan Kartini Bali yang telah memberikan dukungan baik moril maupun materiil sehingga kegiatan pengabdian masyarakat ini dapat terwujud. Tim pengabdi juga mengucapkan terimakasih kepada mahasiswa Prodi D III Kebidanan yang ikut berpartisipasi dalam kegiatan ini.

\section{Daftar Referensi}

Darmalaksana, W. (2020). WhatsApp Kuliah Mobile. Fakultas Ushuluddin UIN Sunan Gunung Djati Bandung.

Hasanah et al (2020). Gambaran Psikologis Mahasiswa dalam Proses Pembelajaran Selama Pandemi Covid-19 ; Jurnal Keperawatan Jiwa, 8 (3), 299-306

Pangondian, R. A., Santosa, P. I., \& Nugroho, E. (2019). Faktor-Faktor Yang Mempengaruhi Kesuksesan Pembelajaran Daring Dalam Revolusi Industri 4.0. In Seminar Nasional Teknologi Komputer \& Sains (SAINTEKS), 1(1).

Putri Ayu Fitria,dkk (2020). Dampak Pembelajaran daring terhadap kesehatan Mental Mahasiswa Semester Awal. Jurnal Riset Kesehatan Nasional,Voluem 4(2), hal 6066.

Nurhasanah, S., \& Sobandi, A. (2016). Minat belajar sebagai determinan hasil belajar siswa. Jurnal Pendidikan Manajemen Perkantoran (JPManper), 1(1), 128-135.

Sukma Adnyani, N., \& Krisda Elvina, V. (2021). Jurnal Kependidikan: Analisis SWOT Pembelajaran Daring Mahasiswa Kebidanan Pada Masa Pandemi Covid-19 Prodi DIII Kebidanan Politeknik Kesehatan Kartini Bali * Corresponding Author . Email : sukmaadnyani@gmail.com Jurnal Kependidikan : Pendahuluan Pandemi, $7(2), 437-445$. 